\title{
MACAR TARIHIINDE BİR KIRILMA NOKTASI: TRİANON BARIŞ ANTLAŞMASI (4 HAZİRAN 1920)
}

\section{Gökhan DILBBAŞ*}

ÖZ: Macar tarihinin en önemli kırılma noktalarından birisi 4 Haziran 1920 tarihinde Macaristan ve İtilaf Devletleri arasında imzalanan Trianon Barış Antlaşması'dır. Bu antlaşma ile I. Dünya Savaşı Macaristan adına sona erer, ancak Macaristan ciddi anlamda toprak kaybına uğrar, ekonomik olarak sarsılır ve Orta Avrupa'da yeni devletler ortaya çıkar. Bununla beraber Trianon Barış Antlaşması sorunları kesin şekilde çözemez ve hem Macaristan hem de Orta Avrupa adına yeni ve daha zorlu süreçler ortaya çıkar. Trianon Barış Antlaşması'na giden sürecin, Antlaşma'da Macaristan'ın uğradığı kayıpların, Antlaşma sonrasında Orta Avrupa'da yaşanan değişimlerin ve Antlaşma'nın Avrupa'ya olan etkilerinin incelenmesi XX. yüzyılda iki büyük savaş yaşamış olan Avrupa'nın tarihinin daha bütüncül şekilde anlaşılmasını sağlayacağı gibi, Antlaşma'nın Macaristan'a ve Macar insanına olan etkilerinin de bir kez daha gözden geçirilmesine katkı sağlayacaktır.

Anahtar Kelimeler: Trianon Barış Antlaşması, I. Dünya Savaşı, Macaristan, Wilson İlkeleri.

\section{A BREAKING POINT IN HUNGARIAN HISTORY: TRIANON TREATY OF PEACE (4 JUNE 1920)}

ABSTRACT: One of the most significant breaking points in Hungarian history is the Trianon Treaty of Peace executed between Hungary and the Entente States on 4 June 1920. With this treaty WW I ends for Hungary but Hungary losses significant amounts of territory, shatters economically and new states appear in the Central Europe. On the other hand, Trianon Treaty of Peace does not bring a final solution for the problems and results with new and more difficult processes for both Hungary and the Central Europe. Examination of the process going towards Trianon Treaty of Peace, losses suffered by Hungary in the Treaty and the changes in the Central Europe after the Treaty shall enable better understanding of Europe which experienced two big wars in the XX Century and shall also contribute to review the effects of the Treaty on Hungary and Hungarian people.

Keywords: Trianon Treaty of Peace, World War I, Hungary, Wilson Principles.

*Dr. İstanbul, Türkiye, gokhandilbas@hotmail.com, ORCID: https://orcid.org/0000-0003-4337-8700 


\section{Giriş}

İnsanlık tarihinin o güne kadar gördüğü en uzun ve en y1kıcı savaș olan I. Dünya Savaş1 (1914-1918) sonunda galip gelen İtilaf (Anlaşma) Devletleri İngiltere, Fransa, Rusya, İtalya, Japonya, Sırbistan, Romanya, Belçika, Karadağ, Yunanistan, Portekiz, Amerika Birleşik Devletleri ve Brezilya yenik düşen İttifak (Bağlaşma) Devletleri - Avusturya-Macaristan İmparatorluğu, Almanya, Osmanlı İmparatorluğu ve Bulgaristan - ile antlaşmalar yaparak dört yıl süren savaşı sona erdirirler ${ }^{1}$.

Sovyetler Birliği ile 3 Mart 1918 tarihinde Brest-Litowsk Antlaşması, Almanya ile 28 Haziran 1919 tarihinde Versay (Versailles) Antlaşması, Avusturya ile 10 Eylül 1919 tarihinde Sen Jerman (Saint-Germain) Antlaşmas1, Bulgaristan ile 27 Kasım 1919 tarihinde Nöyyi (Neuilly) Antlaşması ve Osmanlı İmparatorluğu ile 10 Ağustos 1920 tarihinde Sevr (Sevres) Antlaşması imzalanır. İtilaf Devletleri, Macaristan ile de savaşın bitiminden iki yıl sonra 4 Haziran 1920 tarihinde "Trianon Barış Antlaşması"nı imzalar ve I. Dünya Savaşı, Macaristan (Macar Krallığı) adına resmen sona erer².

\section{Trianon Barış Antlaşması Öncesi Yaşanan Gelişmeler}

Amerika Birleşik Devletleri'nin 1917 yılında I. Dünya Savaşı'na katılması ile savaşın kaderi değişir ve yaşanan yenilgiler sonucunda Avusturya-Macaristan İmparatorluğu, Almanya'nın ateşkes kararına uyarak 4 Ekim 1918 tarihinde I. Dünya Savaşı'ndan çekilir. 17 Ekim 1918 tarihinde Macaristan Başbakanı István Tisza (1861-1918), Parlamento'da yaptığı konuşmada Avusturya-Macaristan İmparatorluğu'nun savaşı kaybettiğini ve savaştan çekildiğini açıklar ${ }^{3}$. Karışık olan durumun daha da kötüye gitmesini engellemek için Budapeşte'de 23 Ekim 1918 tarihinde "Nemzeti Tanács" adı altında ulusal bir konsey hükümeti kurulur ve 30 Ekim 1918'de Mihály Károlyi (1918-1919) Macaristan Başbakanı ilan edilir .

\footnotetext{
${ }^{1} \mathrm{http}: / /$ www.tarihin.com/1 dunya-savasi/482-ittifak-ve-itilaf-devletleri.html

${ }^{2}$ http://www.tariharastirmalari.com/birincidunyasavası.html; http://ataturkinkilaplari.com/ave a/57/birinci-dunya-savasi-sonunda-imzalanan-antlasmalar.html; Péter Árpád Harmat, "A trianoni békeszerződés"

${ }^{3}$ Naciye Güngörmüş, Macaristan'da Değişim ve Demokrasiye Geçiş (1989-2009), Köksav Yayınları, Ankara, 2010, s. 65; Britain-Hungary and The Paris Peace Conference of 1919, s. 6; Muzaffer Şen, Yurt Tutuştan Trianon'a Macaristan, Çizgi Kitabevi, Konya, 2016, s. 313. ${ }^{4}$ N. Güngörmüş, age, s. 65; M. Şen, age, s. 314-316; Pierre Renouvin, 1. Dünya Savaşı 19141918, Çev: Adnan Cemgil, Altın Kitaplar Yayınevi, üçüncü baskı, (basım yeri belirtilmemiş) 1982, s. 487; Gyula Kristó-János Barta-Jenő Gergely, Magyarország Története Elöidőktől 2000-ig, Pannonica Kiadó, (basım yeri belirtilmemiş) 2002, s. 498; Romsics Ignác, “Trianon okai", s. 5; P. Á. Harmat, "A trianoni békeszerződés".
} 
Savaşın kaybedilmekte olduğunu gören Macaristan'da zaten savaşın bitmesinden daha birkaç hafta önce savaş sonunda yapılacak görüşmeler için bir taslak plan oluşturmak üzere toplantılar yapılmaya başlanır. 1918 yılının Kasım-Aralık aylarında Budapeşte'de bulunan Iparmüvészeti Múzeum'da Kont Pál Teleki (1879-1941), coğrafya uzmanları Zsigmond Bátky (18741939) ve Aurél Littke (1872-1945) tarafından Macaristan'ın tarihi, doğal, ekonomik ve politik şartları göz önüne alınarak savaş sonrası yapılacak görüşmelerde kullanılmak üzere Karpatlar Havzası'ndaki Macar nüfus bölgelerini kırmızı renk ile gösteren ve "Vörös Térkép" diye anılan bir harita tasarlanır. Harita hazırlanırken Macar Krallığı'nın yarısından fazlasının ana dilinin Macarca olduğunu belirten 1910 yılındaki nüfus sayımı verileri de dikkate alınır ${ }^{5}$.

Avusturya-Macaristan İmparatoru I. Károly (1916-1918), 11 Kasım 1918 - bazı kaynaklara göre 13 Kasım $1918^{6}$ - tarihinde Macaristan Krallı̆̆ 1 ve Avusturya-Macaristan İmparatorluğu üzerindeki haklarından feragat ettiğini açıklar. $\mathrm{Bu}$ suretle Avusturya-Macaristan İmparatorluğu dağılır ve Macaristan'da 1866 y1lından beri devam etmekte olan Düalizm Dönemi sona erer ${ }^{7}$. Kont Ottokar Czernin (1872-1932) bu durumu "Avusturya-Macaristan Imparatorluğu tarihe karıştı" diyerek özetler". $\mathrm{Bu}$ gelişmenin ardından Ulusal Konsey, Macaristan'da cumhuriyet ilan eder. Bu arada 13 Kasim 1918 tarihinde imzalanan Belgrad Ateşkes Antlaşması ile Sırpların Güney Macaristan'1, Romenlerin Erdel'i ve Çeklerin de Slovakya'yı işgal etmesinin önü açılır".

Slovakya'nın ve Erdel'in kaybı, Macaristan'da işsiz sayısının devamlı surette artmas1 ve İtilaf Devletleri'nin sonu gelmez toprak talepleri karşısında Mihály Károlyi ve Ulusal Konsey iktidarda daha fazla kalamaz ve Mart 1919'da istifa eder. 21 Mart 1919 tarihinde Béla Kun (1886-1938) başkanlığında Macaristan Konsey Cumhuriyeti kurulur. Ancak Kun başkanlığında kurulan bu hükümet Macaristan'ın toprak bütünlügünü gözetemez, İtilaf Devletleri tarafindan tanınmaz ve 18 Ocak 1919 tarihinde Paris'te başlayan barış görüşmelerine de davet edilmez. Bu gelişmeler yaşanırken Macaristan, Romen ve Çek-Slovak ordusunun işgaline sahne

\footnotetext{
5 Sándor Szakály, “Trianon”, Magyar Napló, (21. évf.) 6. sz., 2009, s. 11; Dániel Gazsó, "Volt egyszer egy Trianon", Valóság, (58. évf.) 8. sz., 2015, s. 75; István Szakály, "A Trianon-szindróma" Hitel, 23. évf., 6. sz., 2010, s. 17-18.

${ }^{6}$ P. Renouvin, age, s. 489.

${ }^{7}$ P. Renouvin, age, s. 487.

${ }^{8}$ P. Renouvin, age, s. 487.

${ }^{9}$ M. Şen, age, s. 332; P. Á. Harmat, "A trianoni békeszerződés”; László Gulyas, “A Short History of the Treaty of Trianon", s. 4.
} 
olur. Romenler ilk önce Tisa nehrinin doğu kıyıları boyunca tüm bölgeyi işgal eder, Budapeşte'ye altmış mil kadar yaklaşırlar. Çek-Slovak ordusu ise Tisa boyunca ilerleyerek Sátoraljaújhely'i ve Miskolc'u alır. Romen birlikleri 3 Ağustos 1919 tarihinde Budapeşte'ye girer ve 14 Kasım 1919'a kadar şehirde kalır. Bu arada Kun hükümetinin politik görüşlerini beğenmeyen Macarlar Szeged'te Ulusal Ordu Başkomutanı Amiral Miklós Horthy (1868-1957) başkanlığında muhalif bir hükümet kurarlar. Horthy kendisine bağlı ordu birlikleriyle beraber 16 Kasım 1919'da Budapeşte'ye girer ve 19 Kasım 1919 tarihinde Kun hükümetini devirerek Macaristan'a hâkim olur ${ }^{10}$.

Macaristan'da bu gelişmeler yaşanırken İtilaf Devletleri, Macaristan ile barış yapmak için harekete geçerler. $\mathrm{Bu}$ amaçla İngiliz Dışişleri Savaş Departmanı Başkanı Sir George Russel Clark (1874-1951), 23 Ekim 1919 tarihinde görüşmeler yapmak üzere Budapeşte'ye gelir ve içlerinde Miklós Horthy'nin de bulunduğu Macar devlet adamları ile görüşür. Barış görüşmelerinin yapıldığ 1 Paris'e dönüşünde görüşlerini şu şekilde açıklar: “... Macarların genel itibariyle İtilaf güçleriyle işbirliği yapma arzusunun olduğu görülmektedir. Yaptıklart hatalart net bir şekilde görmeye, öte yandan Avusturya'nın politikasinı bertaraf etmenin sorumluluğunu üstlenmeye başlamışlardır, iyi niyetlerini göstermek istiyorlar, yoksa Avurturya'nın ardından Almanya ile yakınlaşmaya mecbur kalacaklar" 11. Hem Clerk'in görüşleri, hem Kun hükümetinin yönetimden çekilmesi ve hem de Macaristan'da yaşanan iktidar arayışlarından sonra Károly Huszár (1919-1920) başkanlığında bir hükümetin kurulup durumun biraz sakinleşmesinin ardından barış konferansının başkanlığını yürütmekte olan Fransız Başbakanı Georges Cleamanceau (1917-1920), 1 Aralık 1919 tarihinde “... Müttefik ve Birleşik Kuvvetler ile barış yapması için" Macar hükümetine çağrida bulunur' ${ }^{12}$.

Macar hükümetinin 2 Aralık 1919 ve 8 Aralık 1919 tarihli toplantılarının ana konusu barış görüşmelerine katılma çağrısı ve İtilaf Devletleri'nin öne süreceği şartlara ne şekilde cevap verilebileceği olur. Bu toplantılara bakanların dışında Kont Pál Teleki, Kont István Bethlen (1874-1946), Kont Albert Apponyi (1846-1933) ve Miklós Horthy de katılır. Görüşmeler sırasında Miklós Horthy, Macaristan'ın içinde bulunduğu durumu gerçekçi bir bakış açısıyla değerlendirir ve görüşmelere katılmayı ertelemenin daha

${ }^{10}$ N. Güngörmüş, age, s. 65-66; M. Şen, age, s. 390.

11 S. Szakály, "Trianon", s. 11; M. Şen, age, s. 386; P. Á. Harmat, "A trianoni békeszerződés".

${ }^{12}$ S. Szakály, “Trianon”, s. 11; Britain-Hungary and The Paris Peace Conference of 1919, s. 10; M. Şen, age, s. 392. 
olumsuz sonuçlar doğuracağını ifade eder: “... İtilaf Devletleri karşısında güvenilir olmamı gerekir ve şayet İtilaf Devletleri'ne karşı şimdi yapacă̆ımı hatalı bir davranış sadece bugün değil, gelecekte de önemli bir faktör olarak çok hatalı bir politika olur"'13.

Yapılan tartışmaların ardından Macaristan'ın devam etmekte olan barış görüşmelerine katılmasına karar verilir. Macar heyeti Kont Albert Apponyi'nin başkanlığında 5 Ocak 1920 tarihinde Paris'e hareket eder. Heyette Apponyi'den başka Kont Pál Teleki, hükümet yetkilisi Kont István Bethlen (1874-1946), Baron Vilmós Lers (1869-1923), eski adalet bakanı Béla Zoltán (1865-1929) ve Kont László Somssich de (1874-1956) bulunuyordu. Apponyi görevinin zor olduğunun bilincindeydi: "Görevlerin en hüzünlüsünü reddedemezdim ama yumuşama sağlayabileceğim konusunda boş hayallere de kapılamıyordum"14. Macar heyeti, görüşmeler sırasında Wilson İlkeleri temelinde halk oylaması önerilmesi seçeneği üzerinde özellikle duracaktır:

"Itilaf Devletleri ile devam etmekte olan nota teatilerinin temelini bölgesel katılımlarımıza olan bağlılığımız sağlayacaktır. Buna doğal hak olarak sahip olduğumuz gibi, tarihi hak olarak da sahip olduğumuzu, savaş süresince dünya halkları arasında ortaya çıkmış olan halkların kendi kaderleri üzerinde söz sahibi olma düşüncesine uymaya hazır olduğumuzu ve bu şekilde Wilson Illkeleri temelinde halk oylaması önereceğimizi ilan edeceğiz. Bu iki öneri, bilindiği gibi bölgesel katılıma olan bağlılı̆̆ımız, öte yandan da halk oylamast talebi savunulmazsa, o takdirde bu iki ilkenin kabul edilmesinin yanı sıra görüşmelere katılmamız ve haklılı̆̆ımızı savunmak için çaba göstermemiz gerekecektir"15.

7 Ocak 1920 tarihinde Paris'e gelen Macar heyeti yaklaşık bir hafta bekledikten sonra 15 Ocak 1920 tarihinde Fransız Dışişleri Bakanlı̆̆ı'ndan barış şartlarını öğrenir. Şartların aşırıcı derecede ağır olduğunun görülmesi üzerine Kont Albert Apponyi, barış şartları üzerine bir konuşma ve savunma yapmak ister. 16 Ocak 1920 tarihinde Fransızca başladığı, İngilizce devam ettiği ve İtalyanca bitirdiği konuşmasında Macaristan'ın

\footnotetext{
${ }^{13}$ S. Szakály, "Trianon”, s. 12.

14 Margaret Macmillan, 1919 Paris Barış Konferansı ve Dünyayı Değiştiren Altı Ayın Hikâyesi, ODTÜ Yayıncılık, Ankara, 2004, s. 265'ten aktaran M. Şen, age, s. 419; Csaba L. Kohalmi, "Historical Notes on the Hungarian Peace Delegation of 1920", The News of Hungarian Philately, Volume: 32/Number: 2, Apr-Jun 2001, s. 4; P. Á. Harmat, "A trianoni békeszerződés".

${ }^{15}$ S. Szakály, “Trianon”, s. 12.
} 
amacının yalnızca Tarihi Macaristan ${ }^{16}$ topraklarının bütünlüğünü sağlamak olduğunu; bunun yanı sıra tarihi, coğrafi, kültürel ve dilsel-etnik değerlerin de aynı şekilde muhafaza edileceğini belirtir ${ }^{17}$ :

“... Bir zamanlarki toprağımız olan Tarihi Macaristan'ın çıkarına olmak üzere halklart ilgilendiren sorunlart onlara soralım şeklindeki önerimiz sizlerin gözünde tatmin edici kararlar haline dönüşmemiştir" ${ }^{18}$. Ayrıca şunları da vurgular: "Bunu talep ettiğimiz zaman Başkan Wilson tarafindan dikkat çekici bir şekilde ifade edilmiş olan değerli görüşe, yani hiçbir insan topluluğunun, devletlerin nüfusunun tek bir bölümünün dahi ikamet etme isteği sorulmadan bir koyun sürüsü gibi yabancı bir devletin yönetimi altına verilmeyeceği hükmünü esas allyoruz. Ayrıca makul düşüncenin ve ortak maneviyatın çıkarımı olan bu önemli düşünce adına şimdi bizden ayrılmak istenen vatanımızın ilgili bölümleri için halk oylaması talep ediyoruz. Nasıl olursa olsun halk oylamasının sonucunu öncelikle kendimizin sunacağını belirtirim"19.

Öte yandan Macar milletinin savaş sonrası ortaya çıkan durumdan sorumlu tutulamayacağının da altını çizer:

“... Galip tarafta olan Siz Beyler, Sizler eskiden düşmanınız olan Merkezi Kuvvetlerin suçlu olduğunu belirttiniz ve savaşın sonuçlarından onlar sorumlu tutmaya karar verdiniz. Öyle olsun; ancak o zaman siralama oluşturulurken suçun derecesiyle orantıll gitmesi gerektiğini ve en sert ve varlığını oldukça tehdit eden şartlarla Macaristan'ı zor durumda bıraktı̆̆ından dolayı bütün milletler içinde en suçlusunun da o (Macar milleti, ç. n.) olduğunu düşünüyorum. Beyler! Bu sorunun ayrintılarına girmiyorum, zira sunduğumuz belgeler savaşın çıktığı anda tam bağımsız olmayan ve yalnizca Avusturya-Macaristan Monarşisi'nin meselelerine dâhil olmuş ve ortaya konan son belgelerin kanttladiğ üzere savaşa sebebiyet veren süreçleri de onaylamayan bir millet hakkında bu hükmü vermenin mümkün olamayacağını ortaya koyacaktır"20.

Macarların Konferans'da Pál Teleki tarafindan hazırlanan harita üzerinden haklılıklarını ispat etmesi, durumu gerçekçi şekilde

${ }^{16}$ Tarihi Macaristan: Kuzeyde ve doğuda Karpat Dağları ile çevrili, güneyde Adriyatik Denizi, Una, Sava ve Tuna nehirleri ile sınırlanan, batıda ise Alp Dağları'na kadar uzanan bölge (http://www.bibl.u-szeged.hu/ha/gazd/stat/ezerev39.html).

${ }^{17}$ Andrew L. Simon, Admiral Nicholas Horthy: Memoirs, Simon Publications, 2000, s. 134; Britain-Hungary and The Paris Peace Conference of 1919, s. 10; Zoltán Bodolai, The Unmaking of Peace, The Fragmentation and Subsequent Destruction of Central Europe After War One By The Peace Treaty Of Trianon, 1980, Australia, s. 20; R. Ignác, agm, s. 9; M. Şen, age, s. 421; L. Gulyas, agm, s. 6.

${ }^{18}$ S. Szakály, "Trianon", s. 13.

${ }^{19}$ S. Szakály, "Trianon”, s. 13; R. Ignác, agm, s. 8.

${ }^{20}$ P. Á. Harmat, "A trianoni békeszerződés". 
değerlendirmesi ve İtilaf Devletleri'nin sunduğu barış şartları karşısında kararlı bir tutum takınmaları etkisini gösterir, hatta Macaristan lehine birtakım iyileştirmeler yapılması ihtimali ortaya çıkar, ancak bu durum önemini kısa sürede kaybeder. Macar heyeti 18 Ocak 1920 - bazı kaynaklara göre 20 Ocak $1920^{21}$ - tarihinde Macaristan'a geri döner. Kont Pál Teleki gelişmelerle ilgili şöyle yazacaktır:

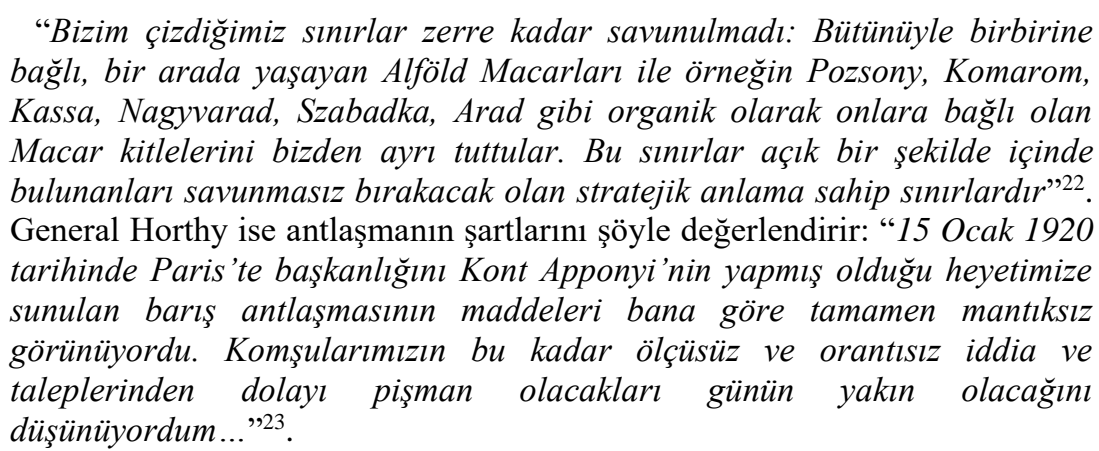

İtilaf Devletleri'nin kabul edilmesini beklediği şartlar konusunda Macar Meclisi'nde heyecanlı tartışmalar olur, hatta Macar temsilcileri 9-12 Şubat 1920 tarihleri arasında Macar tarafinın görüşlerini İtilaf Devletleri'ne bir kez daha iletirler. Macar hükümetinin bu aşamadaki tek düşüncesi yeni kurulan devletlerin sınırları içerisinde kalan, ancak nüfusunun neredeyse tamamı Macarca konuşan Pozsony, Kassa, Komarom, Nagyvárad, Szatmár, Arad, Kolozsvár ve Szabadság gibi yerleşim yerlerinin Macaristan sınırları içinde kalması ve Macar milletinin bütünlügünün sağlanmasıdır ${ }^{24}$. Macarlar, Slovakların, Romenlerin ve Hırvatların yeni kurulan Çekoslovakya'ya ve Yugoslavya'ya dâhil olmasını istememektedir, bulundukları bölgelerde çoğunlukta olduklarını iddia eden ve Macaristan'dan ayrılma talebinde bulunan halkların durumunun ortaya çıkması için halk oylaması talebinde 1srar etmektedirler. Kont Apponyi, Macaristan'ın halk oylamasından çıkacak sonucu kabul edeceğini belirtmesine rağmen İtilaf Devletleri halk oylamas yapılması konusunda ikna edilemez ${ }^{25}$. Oysaki Amerika Birleşik Devletleri Başkanı Thomas Woodrow Wilson (1913-1921) tarafindan hazırlanan ve on dört maddeden oluşan "Wilson Illkeleri"nin Avusturya-Macaristan İmparatorluğu ile ilgili olan onuncu maddesi "Avusturya-

${ }^{21}$ M. Şen, age, s. 423.

${ }^{22}$ S. Szakály, "Trianon”, s. 13; C. L. Kohalmi, agm, s. 4.

${ }^{23}$ A. L. Simon, age, s. 130.

${ }^{24}$ C. L. Kohalmi, agm, s. 4-5.

${ }^{25}$ Z. Bodolai, age, s. 20, 23; S. Szakály, “Trianon”, s. 11. 
Macaristan halklarınin uluslar arasındaki yeri korunmalı ve güvence altına alınmalı, bu halklara özerk gelişme olanağı tanınmalıdır" şeklindedir ${ }^{26}$.

3 Mart 1920 tarihinde İngiltere Başbakanı Llyod George (1916-1922) antlaşma şartlarının Orta Avrupa'da çözüm yerine yeni sorunlara yol açacağını vurgular. İtalya Başbakanı Francesco Saverio Nitti de (1919-1920) Llyod George'nun yanında yer alır. Fransa ise barış şartlarının gözden geçirilmesine ve yeniden düzenlenmesine şiddetle karş1 çıkar. Yapılan tartışmalardan sonra İtilaf Devletleri tarafından kurulacak olan bir "Sınır Düzenleme Komisyonu"nun yapacağı incelemelerden sonra hazırlanacak olan teklifin İtilaf Devletleri tarafından kabulü halinde sınırlarda düzenlemeler yapılabileceği kararına varılır. Ancak bu kararın uygulamada hiçbir yararının olmadığ 1 görülecektir ${ }^{27}$. Macarlar tarafından barış görüşmeleri öncesinde hazırlanmış olan nüfus verilerine dayalı haritayı İtilaf Devletleri kabul etmezler ve görüşmeleri bu harita üzerinden sürdürmezler. İtalya Başbakanı Nitti hatıralarında şöyle yazar: "16 Ocak 1920'de Kont Apponyi, Paris'te Süper Konsey önünde Macaristan'ın haklılı̆̆ını açıkladı̆̆ zaman hissettiğim derin etkiyi gizleyemem (...)Macaristan'ın parçalanışl ve Macaristan'daki üç buçuk milyon Macar ve Alman nüfusunun kurban edilişi hakkında söylediği, ortaya koyduğu rakamlar hiçbir kuşkuya yer birakmiyordu" 28 .

Bu arada Macaristan'da yaşanan politik karışıklıklar yüzünden Károly Huszár başkanlığındaki hükümet 15 Mart 1920 tarihinde istifa eder ve yerine Sándor Simonyi-Semedam (15 Mart 1920-19 Temmuz 1920) başkanlığındaki hükümet gelir. İtilaf Devletleri de Macaristan'daki belirsizlikten ötürü antlaşmanın son halini Macar tarafına 6 Mayıs 1920 tarihine kadar iletemezler. Macaristan'da 10 ve 12 Mayıs 1920 tarihlerinde antlaşmanın kabul edilip edilmemesi, edilmediği takdirde sonuçlarının ne olabileceği üzerine tartışmalar yaşanır. Antlaşmada elle tutulur bir değişikliğin olmaması, Macarlar tarafından önerilen her şartın olumsuz şekilde geri dönmesi ve bu şekilde bir ilerleme sağlanamaması üzerine Kont Apponyi, 16 Mayıs 1920 tarihinde tüm heyetin istifa ettiğini açıklar ${ }^{29}$. Ancak sonunda Macar tarafında içinde bulunulan zor koşullar dikkate alındığında şartların kabul edilmesi, şartlar reddedilirse sonuçlarının daha kötü olabileceği yönünde bir eğilim ortaya çıkar. Türkolog György Hazai (19322016) bu durumu "ellerine verdikleri bu acı reçeteyi kabule mahkûm

\footnotetext{
${ }^{26} \mathrm{http}: / /$ www.tarihiolaylar.com/tarihi-olaylar/wilson-ilkeleri-231

${ }^{27}$ Britain-Hungary and The Paris Peace Conference of 1919, s. 11; R. Ignác, agm, s. 9-10.

${ }^{28}$ S. Szakály, "Trianon", s. 13.

${ }^{29}$ Miklós Zeidler, Trianon, Treaty of, 1914-1918, International Enciklopedia of the First World War; Z. Bodolai, age, s. 23.
} 
oldular" şeklinde değerlendirir ${ }^{30}$. Meclisin 26 Mayıs 1920 tarihinde yapılan oturumunda Kont Apponyi şunları söyler: "Etik bakış açısının ve ulusal hissiyatın - benim de hissiyatımın - en uygun karşılı̆̆ı inkâr edilemez şekilde bugün dünyadaki herkesin karşı olduğu bu imzadır (...)"31.

Sonunda Çalışma Bakanı Ágost Benárd (1920-1921) ve olağanüstü yetkili elçi ve vekil bakan sıfatıla diplomat Alfréd Drasche-Lazar (18751949), Fransa'ya giderek Versailles'deki Büyük Trianon Sarayı'nda 4 Haziran 1920 tarihinde saat 16:32'de on dört bölümden ve 364 maddeden oluşan Trianon Barış Antlaşması'nı imzalar. İmza sırasında Romanya, Çekoslovakya ve Yugoslavya heyetlerinin yanı sıra İtilaf kuvvetlerinin Başkomutanı Mareşal Foch Ferdinand (1851-1929), Fransa'nın Balkan Orduları Başkomutanı General Franchet d'Esperey (1856-1942), Udine Prensi, Yunan Kralı ve konferansın başkanı sıfatı ile o sırada Georges Clemenceau'dan Başbakanlık görevini devralmış olan Başbakan Alexandre Millerand da (Fransa Başbakanı: 20 Ocak 1920-24 Eylül 1920, Fransa Cumhurbaşkanı: 1920-1924) hazır bulunur ${ }^{32}$.

Macar Meclisi antlaşmayı ancak 11 Kasım 1920 tarihinde onaylayabilir. Amerika Birleşik Devletleri ise Macaristan ile yapılan bu antlaşmayı onaylamaz ve Macaristan ile 29 Ağustos 1921 tarihinde ayrı bir barış antlaşmas1 yapar. Macarların 26 Mart-5 Nisan 1921 ve 20-24 Ekim 1921 tarihleri arasında antlaşmanın yeniden gözden geçirilmesi için girişimleri olur, ancak bu girişimlerden elle tutulur sonuçlar alınamaz ${ }^{33}$.

Antlaşma sonrası Macaristan'ın toprak, nüfus ve ekonomik kayıpları

Trianon Barış Antlaşması ile Macar ulusal tarihinde bin yıldan fazla süren bir dönem kapanmış olur. Tarihi Macaristan dağılır ve Macaristan'ın elinde Trianon öncesi sahip olduğu topraklarının ancak üçte biri kalır. Böylece Macaristan'ın Trianon öncesi - Hırvatistan hariç 282 bin - 288 bin kilometrekarelik toprağından - bazı kaynaklar 325,411 kilometrekare der ${ }^{34}$

\footnotetext{
${ }^{30}$ M. Şen, age, s. 463.

${ }^{31}$ S. Szakály, "Trianon", s. 13.

${ }^{32}$ Ayşe Öz, "Trianon Antlaşması ve Macar Şiirine Yansımaları", DTCF Dergisi, 57.1, 2017, s. 92; Orsolya Putz, "Területcsökkentéstől A Megcsonkítáig Trianon-Metaforák", Élet és Tudomány, LXIX. évfolyam, 23. szám, 2014, s. 723-724; Béla Pomogáts, "Trianon a történelemben és a magyar irodalomban", Irodalomismeret, 3. sz., 2015, s. 62; György Juhász, "Trianon és a magyar autonómiak - 1918-tól napjainking", Hitel, (29. évf.), 8. sz., 2016, s. 28-29; I. Szakály, “A Trianon-szindróma”, s. 26. Orsolya Putz, "A figyelemmel kapcsolatos konstruálási müveletek szerepe Trianon konceptualizálásában”, Magyar nyelvőr, (138. évf.) 3. sz., 2014, s. 273; C. L. Kohalmi, agm, s. 5; N. Güngörmüş, age, s. 67; P. Á. Harmat, "A trianoni békeszerződés".

${ }^{33}$ C. L. Kohalmi, agm, s. 6.

${ }^{34}$ Z. Bodolai, age, s. 25.
} 
geriye 93.000 kilometrekarelik bir k1sm1, 18,2 - bazı kaynaklara göre 21 milyon $^{35}$ - milyonluk nüfusundan da geriye 7,6 milyon - bazı kaynaklara göre 7,9 milyon ${ }^{36}$ - kalır. Trianon ile beraber Kral Aziz István (1000-1038) tarafından kurulan Macaristan'ın topraklarının \%67,3'ü - bazı kaynaklara göre $\% 72{ }^{\prime} \mathrm{si}^{37}$ - ve nüfusunun $\% 58,4$ ü - bazı kaynaklara göre $\% 60{ }^{\prime 38}$ yeni sınırlarının dışında kalır (1,6 milyon Macar Romanya'da, bir milyon Macar Çekoslovakya'da, yarım milyon Macar Yugoslavya'da ve 70.000 Macar Avusturya'da). Bazı kaynaklar tam rakam verirler: 3.219.579) ${ }^{39}$. Macar şairi Gyula Illyés'in (1902-1983) "soydaşlarımız, ancak vatandaşlarımız değil" 40 şeklinde tanımladığı yaklaşık olarak 3,5 milyon Macar, Trianon'dan sonra yaşamlarını yabancı ülkelerin topraklarında sürdürmek zorunda kalır. Tarihi Macaristan toprakları üzerinde Çekoslovakya ve daha sonra Yugoslavya adını alacak olan Sırp-HırvatSloven Krallığı adı altında daha küçük ve çok uluslu olmayan devletler kurulur ${ }^{41}$.

Trianon Barış Antlaşması ile Romanya, Erdel'in yanı sıra Tisa Nehri'nin ve Bánát'ın doğu kısmına sahip olur; Yugoslavya, Hirvatistan'ın ve Slovenya'nın yanı sıra Bánát'ın batı kısmını ve Bácska'nın neredeyse tamamını alır; Kárpátalja ve Macaristan'ın kuzeyindeki topraklar yeni kurulan Çekoslovakya'ya bırakılır; Polonya, Szepes bölgesini ve İtalya ise Macaristan'ın tek liman kenti olan Fiume'yi (günümüzdeki adı: Rijeka) alır. Böylece Macaristan'ın denize çıkış imkânı da ortadan kalkmış olur ${ }^{42}$.

Tarihi Macaristan toprakları ve halk1; Macaristan, Avusturya, Çekoslovakya, Polonya, Romanya, Yugoslavya ve İtalya arasında paylaşılır. Romanya topraklarını genişletir, Çekoslovakya, Polonya ve Yugoslavya, Tarihi Macaristan topraklarından elde ettikleri üzerinde pay sahibi olurlar. $\mathrm{Bu}$ devletler ya var olan, ancak I. Dünya Savaşı sonrasında topraklarını genişletme peşinde koşan, ya da savaştan sonra kurulan ülkelerdir. Bunlar arasında Romanya'nın tek başına Macaristan'a bırakılan topraktan daha

${ }^{35}$ Gy. Kristó-J. Barta-J. Gergely, age, s. 516.

${ }^{36}$ A. Öz, agm, s. 92.

${ }^{37}$ Gy. Juhász, agm, s. 28.

${ }^{38}$ Gy. Juhász, agm, s. 28.

39 N. Güngörmüş, age, s. 67; A. Öz, agm, s. 92; P. Orsolya, "Területcsökkentéstől A Megcsonkítáig Trianon-Metaforák", s. 723-724; B. Pomogáts, agm, s. 62; Gy. Juhász, agm, s. 28-29; Gy. Kristó-J. Barta-J. Gergelyi, age, s. 516; R. Ignác, "Trianon okai”, s. 1; Andrew Cronin, "Historical Notes on the Hungarian Peace Delegation of 1920", The News of Hungarian Philately, Volume: 32/Number: 2, Apr-Jun 2001, s. 3; L. Gulyas, agm, s. 6.

${ }^{40}$ Gy. Juhász, agm, s. 28.

${ }^{41}$ S. Szakály, "Trianon", s. 14.

${ }^{42}$ M. Şen, age, s. 436, 440; A. Öz, agm, s. 92; P. Á. Harmat, "A trianoni békeszerződés". 
fazlasını almış olması Macaristan'ın uğradığı kayıpları değerlendirmek açısından önemli bir ölçüttür. Sadece bu toprak parçası I. Dünya Savaşı'nın en önemli aktörlerinden olan Almanya'nın ve savaşı yenik bitiren Bulgaristan'in kayıplarından bile daha fazladır ${ }^{43}$.

Macaristan, Trianon Barış Antlaşması'nda ekonomisini ayakta tutan tuz, altın ve gümüş madenlerini de kaybeder. Demiryolu ağ 1 felce uğrar. En büyük ormanları, otlakları, en önemli hammadde kaynakları Trianon ile belirlenen sınırlarının dışında kalır, sanayisi ve tarımı büyük zarara uğrar. Sınırların değişmesiyle birlikte 1918-1924 yılları arasında 400.000'in üzerinde göçmen Macaristan'a gelir, ancak gelenlerin ne işi, ne de kalacak bir yeri vardır. Hem elden çıkan topraklardaki yeraltı ve yerüstü zenginliklerinin kaybı, hem de Macaristan'a kısa zamanda yoğun şekilde göç dalgası olması yüzünden Macar ekonomisi ciddi bir darbe alır. Başbakan Pál Teleki, işsiz sayısını azaltmak için gösterdiği çabaların karşılığını alamaz, istifa eder ve yerine István Bethlen (1921-1931) gelir. Bununla beraber Macaristan'daki iktidar arayışları uzun bir zaman Trianon sonrasında yaşanan sarsıntıları ve zorlukları aşmaya yetmeyecek, Macaristan iki dünya savaşı arasındaki dönemde oldukça zorlu süreçlerden geçecektir ${ }^{44}$. Trianon'da Macar ordusu otuz beş bin kişi ile sınırlandırılır, silahı ve mühimmatı önemli ölçüde azaltılır ve Macaristan otuz - bazı kaynaklara göre yirmi ${ }^{45}$ - yıl içinde iki yüz milyon - bazı kaynaklara göre iki yüz on milyon $^{46}$ - altın tazminat ödemeye mecbur bırakılır ${ }^{47}$. Ayrıca hava kuvvetleri bulundurmasina ve silah üretmesine de izin verilmez ${ }^{48}$. Macar ulusal tarihinde önemli yerleri olan Kolozsvár, Nagyvárad, Marosvásárhely, Szatmárnémeti, Temesvár, Szabadka, Arad, Brassó, Pozsony, Nagybánya, Kassa, Komárom, Újvidék, Zenta, Ungvár ve Munkács gibi yerleşim birimlerini de kaybeder ${ }^{49}$.

Bu kadar önemli kayıplardan sonra Macaristan için her anlamda yeni bir dönem başlar. Politik görüşlerden ekonomik şartlara, dünyanın ve olayların yorumlanışından Macar insanının kendi kaderine bakışına, edebiyattan mimariye kadar her alanda köklü değişimler yaşanır. Ancak gerek Macaristan sınırları içinde kalan ve gerekse de Macaristan sınırları dışında

${ }^{43}$ M. Şen, age, s. 436, 460.

${ }^{44}$ N. Güngörmüş, age, s. 68.

${ }^{45}$ Gy. Juhász, agm, s. 28; P. Á. Harmat, "A trianoni békeszerződés".

${ }^{46}$ M. Şen, age, s. 446.

${ }^{47}$ S. Szakály, “Trianon”, s. 14; Gy. Juhász, agm, s. 28; M. Şen, age, s. 452; Britain-Hungary and The Paris Peace Conference of 1919, s. 1; Z. Bodolai, age, s. 29.

${ }^{48}$ Gy. Kristó-J. Barta-J. Gergely, age, s. 517; P. Á. Harmat, "A trianoni békeszerződés".

${ }^{49} \mathrm{http}: / /$ www.hunmagyar.org/tor/hungaria.htm 
yaşamak zorunda kalan Macarlar, Trianon Barış Antlaşması'nı kabul etmez, antlaşmayı onur kırıcı bir gelişme olarak değerlendirir ve elden çıkan toprakları "Işsgal edilmiş topraklar" olarak kabul ederler. Macar insanını I. Dünya Savaşı'ndaki ağır ve zor şartlardan, kayıplardan ziyade Trianon'da yaşanan kayıplar daha derin şekilde etkiler, sarsıntıya uğratır ve acı çekmesine sebep olur" ${ }^{50}$ Macar şairi Gyula Illyés bu durumu "Macar, Trianon'dan acı duyandır" sözleriyle özetler ${ }^{51}$. Tarihçi Péter Hanák (19211997) Trianon'un Macarlar üzerindeki etkisini şu cümlelerle ifade eder:

"Savaştaki başarısızlığımız ve Trianon, milleti hazırlıksız yakalamıştı. Salt, gerçek ve kesin olduğu düşünülen her şey birdenbire paramparça olmuştu. Ülkenin ve milletin birliği yok olmuş... aynı zamanda bütün tarihî ve coğrafî gerçekler de... Mağlubiyet travması öylesine derin ve milletin hayatını öylesine şiddetli derecede sarsmıştı ki yıllar, hatta on yıllar boyunca birisinin tarafsı değerlendirmeler ortaya koymasını güçlükle umar olmuştuk." Hanák şöyle devam eder: "Trianon, dünya üzerindeki rolümüzün ve coğrafyamızdaki bütünlüğün tanınmasına ve Tuna havzasındaki halklarla iyi ilişkiler kurulmasına da engel olmuştur. ${ }^{52}$ ",

Macar tarihçisi Ferenc Glatz (1941- ） ise Macar ulusal tarihinde bir dönüm noktası oluşturan Trianon'un revizyonist bir bakış açısı ile değerlendirilmesinden yana değildir ve Orta Avrupa halklarının durumuna vurgu yapar:

“... Sinırlarımız dışındaki Macarlar sorununun ulusal azınlık şeklinde basit bir sorun olmadığ kabul edilmek zorundadır... Bu daha ziyade bölgemizdeki evrensel bir sorundur... Onlart - Macarlarl, Romenleri, Slovaklarl, Sirplart ve Hirvatlarl - tarihin birer kurbanı olarak gören herkes Orta Avrupa halklarının ulusal mağduriyet histerisine bir son vermek zorundadır" ${ }^{\prime 3}$.

Aslında Orta Avrupa'da birlik düşüncesi ve Tuna halklarının işbirliği çabası güncelliğini hiçbir zaman yitirmez. Bu oluşumu Macar devlet adamı Lajos Kossuth'un (1802-1894) ve Macar devlet adamı ve yazar László Teleki'nin (1811-1861) yanısıra XX. yüzyılda Macar şairi Endre Ady (18771919), tarihçi ve politikacı Oszkár Jászi de (1875-1957) ifade eder. Ayrıca

\footnotetext{
${ }^{50}$ S. Szakály, “Trianon”, s. 14; P. Orsolya, “Területcsökkentéstől A Megcsonkítáig TrianonMetaforák", s. 452.

${ }^{51}$ A. Öz, agm, s. 89.

52 A. Öz, agm, s. 93; Péter Hanák, "Viszonylagos nemzettudat" [Relative National Cnsciousness], in Élet es Irodalom [Life and Literature], 25, no. 28 (July 25, 1981): 4-5'den aktaran Stephen Béla Várdy, "The Trianon Syndrome in Today's Hungary", Hungarian Studies Review, Vol. 24, no: 1-2, 1997, s. 74.

53 Vardy\&Vardy, "Treaty of Trianon and Hungarian-Americans," 137-141'den aktaran Várdy, agm, s. 77.
} 
XVIII. yüzyılda Macar jakoben hareketinin önderi Ignác Martinovics de (1755-1795) Macaristan için federatif bir yap1 düşünür. Aslında Tuna halklarının işbirliği düşüncesi çok daha öncelere dayanır. Macar Kralı I. Mátyás'in (1458-1490) Avrupa'da ilerlemekte olan Osmanlılara karş1 bir "Tuna Imparatorluğu" oluşturma düşüncesi Tuna halklarının uzlaşımının ne kadar önemli olduğunun bir göstergesidir ${ }^{54}$.

Avusturya-Macaristan İmparatorluğu'nun toprakları I. Dünya Savaş1 öncesi 676.600 kilometrekare, nüfusu ise 51,3 milyondur ve dilsel-etnik olarak on iki büyük gruba ayrılır. İmparatorluk içinde en büyük çoğunluğu yaklaşık on iki milyon nüfusla Almanlar oluşturur, ancak onların da toplam nüfus içindeki oran $\% 24$ 'ü bile bulmaz. Almanların ardından on milyonluk nüfusla Macarlar gelir, onların da genel nüfus içindeki oranı ancak \%20'dir. Sıralama genel nüfus içindeki oranlarına göre $\% 13$ ile Çekler, $\% 10$ ile Lehler, \%8 ile Ukraynalılar, \%6,5 ile Romenler, \%5 ile Hirvatlar, \%4 ile Sirplar ve Slovaklar, \% 2,5 ile Slovenler ve \%1,5 ile İtalyanlar şeklindedir. 1866 y1lında başlayan Düalizm Dönemi'nden sonra Habsburg İmparatorluğu toprakları üzerinde artık iki devlet bulunmaktadır: Avusturya İmparatorluğu ve Macar Krallığı. Habsburgların sahası Bukovina'dan başlar, Galiçya, Çek toprakları ve Avusturya mülkleri boyunca Dalmaçya'ya kadar uzanarak Krallık Macaristanı ve Hırvatistan şeklinde ayrılmış olan Macar Krallığ sınırlarına kadar ulaşır. Avusturya İmparatorluğu'nun yüzde \%35'inin anadili Almanca iken Macar Krallığı'nın \%48'inin anadili Macarca'dır ${ }^{55}$.

Trianon Barış Antlaşması, bu büyük imparatorluğun bir parçası olan Macaristan'1 Avrupa'nın ortasında küçük, tek başına ve Karpatlar Havzası'na sıkışmış bir devlet durumuna getirir. Macaristan artık yüzyıllar boyunca hâkim olduğu topraklar üzerinde kurulmuş yeni komşularıyla birlikte yaşayacaktır. Macar şairi Attila József'in (1905-1937) A Dunánál (1936) başlıklı şiirinde “... Árpád ve Zalán, Werböczi ve Dózsa/Türk, Tatar, Slovak, Romen/Hepsi bu yürekte kaynaşmış ..."56 şeklinde belirttiği gibi Macaristan'ın tarihi boyunca tek uluslu bir yapıya sahip olmadığı bir gerçektir. Bu durum I. Dünya Savaşı öncesinde de geçerliliğini korumaktadır. Macarların genel nüfus içindeki oranı XIX. yüzyılda tedrici olarak artmış olsa da XX. yüzyılın ilk yıllarında \%50'yi ancak geçer. 1910 nüfus sayımı verilerine göre Macaristan'ın nüfusunun sadece \%54,6's1 Macar kökenlidir. Nüfusun geri kalanını ise Romenler, Slovaklar, Almanlar, Sırplar ve Hırvatlar oluşturur. Tarihi Macaristan'ın etnik dağılımına dikkat

\footnotetext{
${ }^{54}$ N. Güngörmüş, age, s. 40; B. Pomogáts, agm, s. 73.

${ }^{55}$ R. Ignác, agm, s. 1-2.

${ }^{56}$ http://www.mek.oszk.hu/00700/00708/html/kolto00000/kotet00001/ciklus00486/cim00490.
} 
edecek olursak Macaristan'ın ortasındaki bölgelerde Macar nüfusunun daha yoğun olduğunu görürüz. Bunun dişındaki sahalarda, örneğin Felvidék, Erdel, Bácska ve Hırvat-Sloven bölgelerinde Macarlar yaşamamaktadır. Bu yüzden Macaristan'da Tuna ötesi, Alföld, Felvidék, Erdel ve Délvidék bölgeleri arasında düşünce yapısı, kültürel oluşumlar ve gelenekler birbirinden oldukça farklıdır. Bu farklılıklar Reform Çağında, 1848-1849 Macar Özgürlük Savaşı'nda ve ardından gelen Düalizm Dönemi'nde bir dereceye kadar yumuşar, ancak tamamıla ortadan kalkmaz. I. Dünya Savaşı'na kadar bir şekilde bir arada tutulan etnik gruplar gerek savaşın getirdiği şartlar ve gerekse de savaş sonunda ortaya çıkan durum itibariyle kendi bağımsızlıklarını elde etme çabası içine girerler ve Tarihi Macar Krallığı çatırdamaya başlar ${ }^{57}$.

Prag'daki Ulusal Konsey 28 Ekim 1918'de "Çek halkının, geleceğini belirlemesi için Viyana ile görüşmelere girişmeye gereksinimi yoktur" derken bir gün sonra, 29 Ekim 1918'de Yugoslav Ulusal Konseyi de: "Slovenlerin, Hirvatların ve Sirpların yaşadığ toprakların tek bir devlet durumunda birleştirileceğini" ilan eder. Erdel'deki Romenler de bir ulusal meclis kurmanın peşine düşer ve 1 Aralık 1918 tarihinde Erdel'in Romanya ile birleştiğini açıklarlar. Macaristan'ın tarihi topraklarını elinde tutmasının imkânı kalmaz, Macarların durumu kurtarmak adına son bir ümitle ortaya attığı "Üçlü Devlet Sistemi" azınlıkların ilgisini çekmez. Macar heyetinin Trianon'da hiç olmazsa Macarca konuşan yerleşim yerlerini Macaristan sinırları içinde tutma çabası da bir işe yaramaz ve Macaristan, Trianon sürecinde yalnız kalır ${ }^{58}$. Genç bir İngiliz gözlemcinin 1919 yılında Károlyi’ye söylediği şu cümle aslında Trianon'un çerçevesini çizmektedir: "Antant hükümetlerinin Macaristan'daki on milyon kişinin kaderine kaygllanmaktan çok daha önemli sorunlarl vardl"59.

Wilson İlkeleri her ne kadar ulusların kendi kaderini tayin hakk1, belli bölgelerin kendi kaderlerini halk oylamasıyla belirlemesini şart koşmuş olsa da bu ilkeler I. Dünya Savaşı sonrasında Orta ve Doğu Avrupa'da işlevini yitirir, bu coğrafyanın gerçekleri ve dinamikleri ile çelişir. AvusturyaMacaristan İmparatorluğu sınırları içinde yaşayan küçüklü büyüklü birçok halk artık bağımsız olmanın ve kendi varlığını ispat etmenin peşinde koşmaktadır. Wilson İlkeleri coğrafi, tarihi, kültürel ve ekonomik gerçekler

htm

57 B. Pomogáts, agm, s. 6-8.

58 P. Renouvin, age, s. 486-487; Gy. Kristó-J. Barta-J. Gergely, age, s. 460, 499; BritainHungary and The Paris Peace Conference of 1919, s. 6; M. Şen, age, s. 411.

59 Margaret Macmillan, 1919 Paris Barış Konferansı ve Dünyayı Değiştiren Altı Ayın Hikâyesi, ODTÜ Yayıncılık, Ankara, 2004, s. 265'ten aktaran M. Şen, age, s. 423. 
karşısında duramaz ve Tuna Havzası örneğinde olduğu gibi göz ardı edilir. I. Dünya Savaşı sonunda Orta ve Doğu Avrupa, bağımsızlık peşinde koşan etnik gruplarla doludur. Polonya'nın üçte biri Lehçe konuşmaz, Çekoslovakya'da Lehler, Ruslar, Almanlar, Macarlar ve Rusinler vardır, Trianon sonrası Romanya'nın topraklarında artık bir milyondan fazla Macar yaşamaktadır ${ }^{60}$. Trianon Barış Antlaşması ile topraklarını genişleten veya yeni kurulan devletlerin sınırları aslında o dönemdeki askeri şartlara ve galip devletlerin isteklerine göre şekillenir ${ }^{61}$.

\section{Macaristan'ın Trianon Barış Antlaşmasıı'nda parçalanmasının sebepleri}

I. Dünya Savaşı'nın ilk zamanlarında İtilaf Devletleri'nin Orta-Doğu Avrupa'da yeni ülkeler oluşturmak şeklinde bir fikirleri yoktur. AvusturyaMacaristan İmparatorluğu'nun iç karışıklıklarına ve İmparatorluk içinde bulunan etnik gruplar arasındaki gerginliklere rağmen böyle bir düşünce beslemezler. Savaşın ilk iki yılında İngiltere ve Fransa ne Lehlerin, ne de Çeklerin İmparatorluk'tan ayrılması fikrini destekler. Ancak bu bakış açısı 1916 yılından itibaren değişmeye başlar ve 1918 yılında tamamen farklı bir yapıya bürünür ${ }^{62}$. Bu düşüncenin değişmesinin en büyük sebebi Almanya'da 1915 y1lından itibaren ortaya çıkan Orta ve Doğu Avrupa ile birleşme fikridir ("Mitteleuropa"). Bu durum başta Fransa olmak üzere İngiltere ve diğer bağlaşıkları oldukça tedirgin eder. İtilaf Devletleri 1918 yılında BrestLitowsk Antlaşması ile Rusya'nın savaştan çekilmesi karşısında doğudaki en büyük destekçilerini kaybeder. Bu durumda Dinyeper'e kadar uzanan sahanın Almanya'nın mülkiyetine geçmesi ve yönetilmesi ihtimali İtilaf Devletleri'nin gözünü iyice korkutur. Bu kadar güçlü bir Almanya ve Avusturya-Macaristan İmparatorluğu istemeyen İtilaf Devletleri özellikle Avusturya-Macaristan İmparatorluğu toprakları üzerinde yaşayan halkların özgürlüğü fikrini savunmaya başlar ve bu şekilde İmparatorluğu parçalayarak savaştan sonra Avrupa'da yeni bir düzenin kurulmasından yana tavir alırlar ${ }^{63}$.

Savaş öncesi başta İngiltere olmak üzere Avrupa devletlerinin çoğu Habsburg İmparatorluğu'nun ve onun devamı olan Düalizm yönetiminin devam etmesini istemektedir. Habsburg İmparatorluğu'nun varlığını devam ettirmesinin önemini daha 1849 yllında Lord Palmerston (Henry John

60 J. M. Roberts, Avrupa Tarihi, Cev: Fethi Aytuna, İnkılap, İstanbul, 2010, s. 614-615.

${ }^{61}$ William H. McNeill, Dünya Tarihi, Çev: Alâddin Şenel, İmge Kitapevi, 4. Baskı, Ankara, 1998, s. 553.

${ }^{62}$ R. Ignác, agm, s. 4.

${ }^{63}$ R. Ignác, agm, s. 5. 
Temple, 1784-1865) şöyle belirtir: “Avrupa'nın ortasında duran Avusturya, sinırı geçmeye ve bir tarafin diğer tarafi istilasına karşı bir engel oluşturmaktadır. Avrupa'nın politik bağımsızlı̆̆ ve özgürlükleri büyük bir Avrupalı güç olarak Avusturya'nın bütünlüğ̈̈ne ve devamlılığına bağglıdır..." Amerika Birleşik Devletleri'nin Başkanı Wilson'un da I. Dünya Savaşı'na girerken düşüncesi aynıdır: "Biz Avusturya-Macaristan İmparatorluğu'nun parçalanmasını veya yeniden düzenlenmesini arzu etmiyoruz". Keza İtilaf Devletleri'nin temsilcisi General Jan Christiaan Smuts da (1870-1950) 1917 y1lında Avusturya-Macaristan İmparatorluğu'nun diplomat1 Kont Mensdorff (1861-1945) ile yaptığı görüşmede "Londra'da hiçkimse AvusturyaMacaristan Imparatorluğu'nun parçalanmasını istemiyor" derken Avusturya-Macaristan İmparatorluğu'nun toprak bütünlüğüne vurgu yapmaktadır. Aynı şekilde İngiltere Başbakanı David Llyod George da 1918 y1lında “Avusturya-Macaristan Imparatorluğu'nun etkisi Güneydoğu Avrupa'da güçlü bir konumda bulunmalıdır" demektedir ${ }^{64}$.

1918 yılında LIyod George'nun bu sözlerine karşın daha 1916 yılında İngiltere'de Avusturya-Macaristan İmparatorluğu ile ilgili farklı görüşler hâkim olmaya başlar. 7 Ağustos 1916 tarihli bir bildiride şöyle denilmektedir:

“Küçük veya büyük Avrupa'nın bütün devletlerinin gelecekte barış ve güven içinde ulusal gelişmelerini sağlayabilecek bir konumda olmaları temin edilmelidir... Ulusal istekler kadar bunların gerçekleşmesi için tam yetki verilmesi böyle bir barı̧̧ın zorunlu şartıdır. Bu yüzden savaştan sonra bölgesel düzenleme düşüncesinin unsurlarından bir tanesinin de yönetim olması milliyetçiliğin bir prensibidir... Avusturya-Macaristan'ın geleceğinin geniş ölçüde savaştan sonra ortaya çıkacak olan askeri şartlara bağlı olacă̆ şüphesizdir..." Bildirgenin Macaristan ile ilgili kısmı ise şöyledir: "Ülkede Macarların yaşadığı bölgeler ticari çıkış yolları olan Adriyatik'te Fiume ve Tuna vasitasıla Karadeniz bütünüyle güvence altına alınarak Macaristan bağımsız bir devlet halinde şekillendirilmelidir..."65.

Trianon'da Macarlara bu kadar ağır şartlar sunulmasının bir diğer sebebi de toprak kayıpları sonucunda zayıflamış bir Macaristan'ın Orta Avrupa'da söz sahibi olmak isteyen Avrupa devletlerine bir engel teşkil etmeyeceği düşüncesidir. Avrupa devletleri bu düşüncelerini kısmen Trianon gibi şartları oldukça ağır bir antlaşma ile kısmen de ağırlıklı olarak Macaristan'a karşı

\footnotetext{
${ }^{64}$ Hungary and The Paris Peace Conference of 1919, s. 1-2; L. Gulyas, agm, s. 1.

${ }^{65}$ Britain-Hungary and The Paris Peace Conference of 1919, s. 4-5.
} 
Çekoslovakya, Romanya ve Yugoslavya tarafindan faaliyete geçirilen "Küçük Antant" denilen oluşum gerçekleştirirler ${ }^{66}$.

Aslında Orta-Doğu Avrupa'nın savaştan sonraki akıbetinin ne olacağı daha savaşın başladığı 1914 yılında belli olur. Rus Dışişleri Bakanı Sergej Dmitriyevic Sazonov (1910-1916), 21 Eylül 1914 tarihinde Bükreş’teki Rus Büyükelçisi'ne şu mesaj1 gönderir: “Aşağıdaki talimatı Rusya, Fransa ve Ingiltere adına Bükreş'e iletin: Romen hükümeti Rusya'nın, Fransa'nın ve Ingiltere'nin önerisiyle Erdel'in ve Bukovina'nın Romen bölgelerinin ele geçirilmesinde hem fikirdir, yukarıda adı geçen üç devlet de Bulgaristan'ı muhtemel bir Romen saldirısından geri tutmak için her türlü etkiyi göz önüne alacaktır..." Romanya'nın yeni sınırlarının nereden geçeceği bu sırada daha tam olarak belli değildir. Daha o zamanlar Erdel'in ve Güney Bukovina'nın Romanya'ya, Doğu Galiçya'nın, Rutenya'nın ve Kuzey Bukovina'nın da Rusya'ya verilmesi karara bağlanmıştı́r ${ }^{67}$ Keza Pétervár'daki Fransız elçisi Maurice Paléologue (1859-1944) ile Rus Çarı arasında 1914 Kasımında şöyle bir konuşma geçer: "Sirbistan, Bosna'yl, Hersek'i, Dalmaçya'y ve Kuzey Arnavutluk'u ilhak etsin. Yunanistan, Italya'ya ait olan Avlonya hariç Güney Arnavutluk'u alsın. Bulgaristan, Makedonya'da Strbistan'dan bir taviz koparırsa akıllıca davranmış olur... Ya bu Avusturya-Macaristan'in durumu ne olacak? ..." Paléologue buna ilave olarak şunları söyler: "Çek ülkesi en azından otonom bir yönetim talebinde bulunacaktır" ${ }^{68}$. Fransa'nın as1l amacinın ise Alsas-Loren bölgesini almak ve Almanları yenilgiye uğratmak olduğu açıktır, Rusya ise Lehistan, İstanbul Boğazı ve Balkanlar üzerinde hak talebinde bulunur ${ }^{69}$. 1914 y1lında sadece birer öneri şeklinde sunulan bu düşünceler gelişen süreçlerle beraber savaşın sonuna doğru ete kemiğe bürünür ve daha somut bir hal alır.

Macarların Trianon'da uğradığı kayıplar Amerika Birleşik Devletleri'nde ve Avrupa'da diğer milletlerin zaten kendilerine ait olan toprakları geri alması şeklinde yorumlanır. Hatta Trianon'da Macar heyetine "Bin sene dahi devam edegelse, haksızlık ve zulüm hakka tahvil edilmez" şeklinde bir açıklama ile Macarların kendilerine ait olmayan topraklara sahip oldukları anlatılmaya çalışılır ${ }^{70}$. Ancak Macaristan'ın uğradığı toprak kayıpları halk oylaması yapılmadan ve halkların kendi kaderi üzerinde söz sahibi olmasına

${ }^{66}$ P. Á. Harmat, "A trianoni békeszerződés".

${ }^{67}$ Tibor Hajdu, "Trianon alternatívája”, Magyar Tudomány, (175. évf.), 11. sz., 2014, s. 1296.

${ }^{68}$ T. Hajdu, agm, s. 1297.

${ }^{69}$ T. Hajdu, agm, s. 1296; I. Szakály, “A Trianon-szindróma”, s. 10.

70 Dominicus Kosáry, The History of Hungary, Published and printed in Stockholm 1944 in cooperation with Johannes Lotz'dan aktaran M. Şen, age, s. 449. 
firsat verilmeden gerçekleşir. Macaristan'ın taleplerine Trianon sürecinde olumsuz şekilde yaklaşılmasının temel sebepleri şunlardır: 1) Macaristan, Trianon'da Avusturya ve Almanya gibi mağlup ülkeler sinıfinda değerlendirilir. Macar heyeti 1918 yılında Fransa'nın Balkan Orduları Başkomutanı General Franchet d'Esperey ile ateşkes şartları için masaya oturduğu zaman General'in sözlerinden İtilaf Devletleri'nin Macaristan'a karş1 tutumu zaten ortaya çıkar: "Almanya ile beraber yürüdünüz, onlarla birlikte cezalandirllacaksiniz. Macaristan bunun bedelini ödeyecek... Fransa'ya saldırdınız... Ulusal azınlıklara baskı yaptınız..."71 2) 18 Ocak 1919 tarihinde başlayan Paris Barış Konferansı'nda öncelikli amaç Almanya ile bir antlaşma imzalayıp savaşı bir an önce sona erdirmektir. Macaristan ile yapılacak görüşmelerin taslağının hazırlanması işi ise Macaristan'dan mümkün olduğu kadar çok toprak elde etmek peşinde koşan Romanya, Yugoslavya, Çek ve Slovak komitelerine emanet edilir ${ }^{72}$. Macaristan'ın sınırları belirlenirken Macarların talepleri dikkate alınmaz, Macarlar tarafından hazırlanan nüfus yoğunluğunu gösteren harita değerlendirilmez. Trianon Barış Antlaşması'ndaki şartların teoride Wilson İlkeleri'ne göre hazırlandığı iddia edilse de uygulamada bu ilkelerin dikkate alınmadığ görülür ${ }^{73}$. 3) Trianon Barış Antlaşması, Macar heyetinin Barış Konferansı'nda bulunmadığı bir sırada hazırlanır. Macaristan'ın sınırları 26 Şubat 1919 tarihinde onaylanır. Ancak Macaristan bu esnada kendi iç sorunları ile meşguldur ve birliğini sağlamaya çalışmaktadır. Macaristan'da birbiri ardına yaşanan iktidar değişiklikleri, Budapeşte'nin Romenler tarafından işgali ve ülkede sonu gelmeyen huzursuzluklar yüzünden antlaşma şartları Macar tarafına neredeyse bir yıl sonra durum sükûnete kavuştuğu zaman tebliğ edilir. Üstelik Belgrad Ateşkes Antlaşması sonucunda Sırplar, Romenler ve Çekler Macaristan'ın topraklarını işgal etmiş, yeni sınırlar artık neredeyse belli olmuştur. Bu arada Paris Barış Konferansı'nın çalışmalarında da sona gelinmiştir. Asıl amaç olan Almanya ve Avusturya ile barış yapılmış, Amerika Birleşik Devletleri Başkanı Wilson ülkesine dönmüş ve süreç ilk baştaki heyecanını kaybetmiştit ${ }^{74}$. Macarlar kendilerinin hiçbir katkısı olmayan ve galip devletlerin lehine hazırlanmış olan bir antlaşmayı önlerinde bulurlar.

Trianon Barış Antlaşması'nın Macaristan'a ve Orta Avrupa'ya etkileri

\footnotetext{
${ }^{71}$ M. Şen, age, s. 320.

${ }^{72}$ Britain-Hungary and The Paris Peace Conference of 1919, s. 8-9; L. Gulyas, agm, s. 5.

${ }^{73}$ P. Á. Harmat, "A trianoni békeszerződés".

${ }^{74}$ Z. Bodolai, age, s. 18; Britain-Hungary and The Paris Peace Conference of 1919, s. 8-10; P.

Á. Harmat,"A trianoni békeszerződés"; L. Gulyas, agm, s. 4.
} 
I. Dünya Savaşı sonrası İtilaf Devletleri'nin amacı “milletlerin özgürlüğ̈̈̈’nü sağlamaktır. Trianon Barış Antlaşması, Tarihi Macaristan'ın içinde yaşayan halkların özgürlüğünü bir dereceye kadar sağlamış olsa da aslında daha büyük sorunlara yol açar. Galip devletler Trianon'da bir yandan Macaristan içindeki etnik grupların sorunlarının çözümü için uğraşırken, bir yandan da Orta Avrupa'nın politik, ekonomik ve ulusal sorunlarını çözmeye odaklanır. XIX. yüzyıldan beri süregelen Orta Avrupa'daki gerilim ve mücadele XX. yüzyılın şafağında da devam etmektedir. Çeşitli unsurların katılımıyla gitgide körüklenen bu mücadele sadece bir antlaşma ile kolay kolay çözümlenemezdi. İtilaf Devletleri'nin Orta Avrupa'nın gerçeklerini ve bu coğrafyanın yüzyıllar boyunca Avrupa'da üstünlüğün ve dengenin merkezi konumunda olduğu görüşünü dikkate almadan hazırladıkları Trianon Barış Antlaşması Orta Avrupa'nın sorunlarını çözemez. İki savaş arasında Rusya ve Almanya, Orta Avrupa'daki güçlerini ve etkilerini arttırmanın yollarını arar. Her iki ülke de savaşı kaybetmiş olmasına rağmen Orta Avrupa'yı ellerinde tutarlarsa konumlarının güçleneceğinin farkındadır ${ }^{75}$.

I. Dünya Savaşı'ndan sonra Almanya hayatta kalmayı başarır, makul derecede toprak ve nüfus kaybına uğrar. Rusya ise toprakları üzerinde hâkimiyet sağlar ve yeni düzenini oturtmanın gayreti içine girer. $\mathrm{Bu}$ değişimleri Orta Avrupa'nın küçük ülkeleri yaşayamaz, Almanya'nın ve Rusya'nın genişlemesi ve güçlenmesi karşısında bir ittifak kuramazlar. Trianon sonrasi Tarihi Macaristan'dan toprak alarak kurulan veya topraklarını genişleten ülkeler (Çekoslovakya, Romanya ve Yugoslavya) Macaristan'dan gelebilecek bir tehdit karşısında kendilerini savunmak için aralarında "Küçük Antant" denilen bir birlik oluştururlar ${ }^{76}$. Bu gelişme bile Macaristan'ın Orta Avrupa'da dengelerin sağlanması için ne kadar önemli bir unsur olduğunun ve Trianon ile parçalanan Orta Avrupa'da sükûnun uzun bir süre sağlanamayacağının bir göstergesidir.

Trianon sadece Macaristan'ın trajedisi değildir. Macaristan'ın dağılması ve toprak bütünlüğünün bozulması uzun yıllardır bir araya gelemeyen Orta Avrupa halklarının da uzlaşma imkânını nihai olarak sona erdirir, bu coğrafyanın umutları ve geleceğe dair planları artık geçmişte kalır. Trianon, tarihi gerçeklik olgusuyla hiçbir şekilde bağdaşmadığı gibi Avrupa'nın ortasına sıkışmış küçük halkların varlığını ve kültürel oluşumunu tehdit eden unsurların daha da güçlenmesini sağlar. Avrupa'nın ortasında Macaristan gibi güçlü bir ülkenin sınırları bu kadar daraltılmasaydı Orta Avrupa'nın ve

${ }^{75}$ Z. Bodolai, age, s. 21-22, 30-32.

${ }^{76}$ Z. Bodolai, age, s. 29. 
hatta Avrupa'nın tarihinin çok farklı şekilde seyredeceği, II. Dünya Savaş1 öncesi Almanya'nın frenlenebileceği, II. Dünya Savaşı'nın oluşum şartlarının ve süresinin de değiş̧ebileceği açıktır. Bu durumu aralarında Fransa Cumhurbaşkanı François Mitterand'ın (1981-1995) ve Başbakan Édouard Balladur'un (1993-1995) bulunduğu devlet adamları da dile getirmiştir ${ }^{77}$.

Barış görüşmeleri sırasında savaşın son zamanlarında Macarlar tarafından nüfus verileri dikkate alınarak hazırlanmış olan harita galip devletler tarafından dikkate alınmaz, Macar tarafının haklı talepleri başta Fransa olmak üzere diğer devletler tarafindan reddedilir. Örneğin Pozsony, Komárom, Kassa, Ungvár, Szatmárnémeti, Nagyvárad, Arad ve Szabadka Macar dilinin hâkim olduğu yerlerdir. Kolozsvár'da, Marosvásárhely’de Macarlar çoğunluktadır, Brassó'da, Temesvár'da da Macarlar Almanların arkasından ikinci sırada yer almaktadır. Eğer görüşmeler esnasında Macar nüfus verileri dikkate alınsaydı Macaristan topraklarının üçte birini değil, sadece yarısını kaybetmiş olacakt ${ }^{78}$. Bu durumda ekonomisine güç veren yeraltı ve yerüstü kaynaklarının da kaybı daha az olacak ve Macaristan içine düştüğü sıkıntılardan daha hızlı bir şekilde kurtulabilecek, sınırları bu kadar daralmayacak, stratejik ve jeopolitik konumundan ötürü Orta Avrupa'da bir denge unsuru olarak görev alabilecekti.

\section{Trianon Barış Antlaşması’nın Macar milletine ve Macar edebiyatına etkisi}

Trianon, ülkeyi sadece fiziki olarak parçalamaz, Macarların ruhunda da derin yaralar açar. Macaristan'ın savaş öncesinde de birtakım sıkıntıları olduğu bir gerçektir, ancak Macarlar ulusal birliklerini bir şekilde muhafaza etmeyi başarmışlardır. XX. yüzyılın başında yaşanan I. Dünya Savaşı'nın Macaristan adına yenilgi ile bitmesi, ardından gelen büyük toprak kayıpları ve ulusal birliğin parçalanması sonucunda Macar insanının yaşamındaki her şeyi olumsuz olarak algılaması ve siyah-beyaz görmeye başlaması bir sürpriz değildir $^{79}$. Trianon Barış Antlaşması, Macarlar tarafından Mohaç Savaşı (29 Ağustos 1526) ile birlikte en büyük ulusal felaket olarak kabul edilir. Tibor Mayor, Trianon Barış Antlaşması'nı şu şekilde yorumlar: "Tarihi Büyük Macaristan'ın çarmıha gerilip parçalandığı gündür. O gün, bin senelik bir varlı̆̆a dayanan Macaristan, cebir ve haksızlığın en kaba tezahürü şeklinde,

\footnotetext{
${ }^{77}$ B. Pomogáts, agm, s. 63.

${ }^{78}$ B. Pomogáts, agm, s. 64.

${ }^{79}$ P. Orsolya, “Területcsökkentéstől A Megcsonkítáig Trianon-Metaforák”, s. 725. 
yumruğun empoze ettiği Trianon Antlaşması gereğince ülkesinin üçte ikisini ve ahalisinin beşte üçünü kaybederek parçalanmıştır"

Macar milletinin hiçbir zaman kabul etmediği Trianon Barış Antlaşması'nın imzalandığı gün Macaristan'da okullar ve resmi daireler kapatılır, Macarlar siyah elbiseler giyer ve sokaklara çıkarak sessiz bir yürüyüşle antlaşmayı protesto eder ${ }^{81}$. Ayrıca antlaşmanın imzalanmasından on yıl sonra 1 Haziran 1930 tarihinde Budapeşte'deki Szabadság tér'de antlaşmayı protesto etmek için elli bin kişi toplanır. Burada Trianon Barış Antlaşması'nın imzalandığı dönemde ülkeyi gözü pek insanların yönetmediği fikrinde olan siyaset adamı Nándor Urmáncy (1868-1940) etkili bir konuşma yapar ve "Korkak bir milletin vatanı olmaz" sözü Macarlar üzerinde büyük etki bırakır ${ }^{82}$. Ayrıca 4 Haziran 1930 tarihinde Macar Meclisi bir yas oturumu yapar ve burada Trianon Barış Antlaşması'nı eleştiren konuşmalar yapılır ${ }^{83}$.

Antlaşmadan sonra Macar diline irredantizm (kurtarımcılık) düşüncesinin sloganı haline gelen "Nem, nem soha" (Hayır, hayır asla) gibi ifadeler girer $^{84}$. Macar devletinin sınırları dışında kalan Macarlar için Macaristan artık anavatan olur, "sınır ötesi Macarlar" ve "yabancı ülkelerde yaşayan Macarlar" şeklinde o zamana kadar Macar dilinde yer almayan terimler kullanılmaya başlanır ${ }^{85}$.

Macar insanının düşünce dünyasında derin izler bırakan ve ruhunda büyük sarsıntılar yaratan Trianon Barış Antlaşması Macar edebiyatçılarını da derinden etkiler. Mihály Babits (1883-1941), Dezső Kosztolányi (18851936), Zsigmond Móricz (1879-1942), Attila József, Gyula Illyés (19021983), Károly Kós (1883-1977) ve Sándor Reményik (1890-1941) Macar insanının Trianon sonrası düşünce yapısını ve ruhi dünyasını en iyi şekilde anlatan edebiyatçılardır ${ }^{86}$. Ancak gerek Macar edebiyatçıları, gerekse de Macar milleti Trianon'dan sonra yaşanan en zor zamanlarda bile diğer halklara hasmane bir tutumla yaklaşmaz, aksine komşu kültürlerle ilişki kurmanın, işbirliğini arttırmanın yollarını arar ve Orta Avrupa halklarının birlikte yaşama imkânını daha güçlü bir şekilde değerlendirir. Macar insanı

\footnotetext{
${ }^{80}$ Tibor Mayor, “Macaristan ve Trianon Muahadesi”, Türk Kültürü, Y11: 1970, Sayı: 93, s. 621'den aktaran M. Şen, age, s. 435.

81 Támás László Vizi, "Trianon teóriájánál... rosszabb Trianon praxisa." A békediktátum tizedik évfordulójára - 1930", Közép-Európai közlemények, (6. évf.) 3. (22) sz., 2013, s. 120.

82 T. L. Vizi, agm, s. 121-122.

${ }^{83}$ T. L. Vizi, agm, s. 120.

${ }^{84}$ S. Szakály, "Trianon”, s. 14.

${ }^{85}$ N. Güngörmüș, age, s. 67.

${ }^{86}$ B. Pomogáts, agm, s. 71.
} 
Trianon sonrasında olumsuz düşüncelerden mümkün olduğu kadar hızlı bir şekilde sıyrılmaya çalışır, içine kapanmaz, yalnızlaşmaz ve kültürel izolasyon sürecine girmeyip dış dünya ile bağlarını koparmaz ${ }^{87}$.

\section{Sonuç}

Macar ulusal tarihinde Trianon Barış Antlaşması kadar ülkeyi sarsan ve Macar milletinin hafizasında daimi surette yaşayacak olan daha derin bir trajedi yoktur. Trianon, ancak 1526 yılında Macar Krallı̆̆ı'nın yenilgisi ile biten Mohaç Savaşı'nın yarattığı travma karşılaştırılabilir. Ancak Trianon'un Tarihi Macaristanı bir daha geri döndürülemeyecek şekilde parçalaması sebebiyle Mohaç Savaşı'ndan daha derin bir etki bıraktığı kesindir. Mohaç'tan itibaren başlayan özgürlük mücadelesi, savaşlar, isyanlar ve Macar toplumundaki dalgalanmalar Trianon ile son bulur. Bu antlaşmadan sonra Tarihi Macaristan toprakları üzerinde yeni devletler ortaya çıkar ve bu tarihten itibaren Orta Avrupa'da, hatta tüm Avrupa'da jeopolitik, stratejik ve etnik temele dayalı sorunlar yeni bir boyut kazanır. Tarihi Macaristan'ın bu şekilde parçalanması bölgeye istikrar getirmez ve Avrupa'da uzun yıllar boyunca devam edecek sıkıntılara yol açar.

I. Dünya Savaşı'nı kazanan İtilaf Devletleri'nin asıl amacı savaştan önce Avrupa'nın en büyük gücü olan, başta Avusturya-Macaristan İmparatorluğu olmak üzere diğer İttifak Devletleri’ni de yanına alarak dört yıl boyunca mücadele eden Almanya'nın gücünü kırmak ve yeniden güçlenmesini önlemektir. Bunun dişında Avrupa'nın ikinci büyük gücü olan AvusturyaMacaristan İmparatorluğu'nu da en ağır şekilde cezalandırma ve parçalama prensibini benimserler. Ancak Trianon Barış Antlaşması, Macaristan'ın Avrupa'da kurulmaya çalışılan yeni düzeni kabul etmeyen ülkelerle işbirliği yapmasını, ilerleyen süreçte Almanya'nın ve İtalya'nın yanında yer almasını kolaylaştırır ve sonunda kazançlı çıkmadığı yeni bir savaşın içine sürüklenmesine zemin hazırlar. I. Dünya Savaşı'nı kazanan devletler Orta Avrupa'da uzun yıllardır sürmekte olan politik, ekonomik ve ulusal sorunları bir antlaşma ile çözebileceklerini düşünmüşlerdir. Ancak Orta Avrupa'da yeni bunalımların ortaya çıkması ve savaşın bitiminden yaklaşık yirmi yıl sonra ikinci bir savaşın patlak vermesi Trianon da dâhil olmak üzere I. Dünya Savaşı'nı kaybeden ülkeler ile yapılan antlaşmaların sorunları çözemediğinin bir göstergesidir. Trianon ve ardından gelen kayıplar Macaristan'da sürekli olarak sorgulanır, II. Dünya Savaşı'ndan sonra da Trianon ve sonuçları Macar insanının hafızasından çıkmaz.

\footnotetext{
${ }^{87}$ B. Pomogáts, agm, s. 73.
} 
Trianon Barış Antlaşması'ndan sonra Macar ulusal tarihinde yeni bir sayfa açı1ır. Karpatlar Havzası'nda yüzyıllar boyunca tek vücut halinde yaşamış olan Macar milleti antlaşmanın imzalanması ile birbirinden ayrılır. Trianon Barış Antlaşması ile anayurtlarından edilen Macarlar yeni yurtlarında birçok konuda yıllar boyunca çeşitli sıkıntılar yaşarlar. Trianon Barış Antlaşması, Macar ulusal tarihinde sadece tarihi bir olay, bir kırılma noktası değildir, Macar insanının hafızasında varlığını her zaman koruyacak olan bir semboldür.

Macaristan'da Trianon sonrasında sadece coğrafi, idari ve politik anlamda değil, aynı zamanda dil, tarihi gelenek ve kültürel anlamda da yeni bir birlik sağlanmaya çalışılır. Macarların yaklaşık olarak yüz elli yıl boyunca Türk hâkimiyetinde Krallık Macaristanı, Osmanlı hâkimiyetindeki topraklar ve Erdel Prensliği şeklinde üçe ayrılmış şekilde yaşamaları özellikle XV-XVI. yüzyıllarda ulusal kimliklerini yeniden keşfetmelerini sağlar. Aynı durum bu sefer XX. yüzyılda Trianon Barış Antlaşması ile gerçekleşir ve Antlaşma'nın Macar ulusal hafizasında yarattığı şiddetli sarsınt1 Macarların ulusal kimliklerini yeniden hatırlamalarını ve ona daha çok sahip çıkmaları sonucunu doğurur.

I. Dünya Savaşı'ndan sonra ortaya çıkan yapıda Macaristan'ın savaş öncesi sahip olduğu demografik yapısını ve bütünlüğünü korumasının imkânı artık mümkün değildir. Bunu o zamanki Macar devlet adamları da anlar ve Macaristan'ı bu süreçten en az kayıpla çıkarmanın yollarını aramaya başlarlar. Ancak savaşı kaybetmiş olmaları, İtilaf Devletleri'nin Macarların her önerisine olumsuz yaklaşması ve Macaristan'1 paylaşılacak bir savaş ganimeti olarak görmeleri yüzünden Macaristan'ın I. Dünya Savaşı'nı yenik bitiren devletler içinde en ağır antlaşmayı imzaladığı söylenebilir. Bir zamanlar Avrupa'nın sınır kalesi olarak görülen ve gerisindeki ülkeleri bir kalkan gibi koruyan Macaristan'ın barış görüşmeleri sırasında yalnız kalması ve destek alabileceği bir ülkenin bulunmaması Macaristan adına olumsuz sonuçlar doğurur ve Macaristan I. Dünya Savaşı'ndan bağlaşığı olduğu diğer devletlerden daha ağır bedeller ödeyerek çekilir.

\section{KAYNAKÇA}

Britain-Hungary and The Paris Peace Conference of 1919 (http://www.mfa.gov.hu/NR/rdonlyres/C4E1FE48-6ADA-46B1-979F-

D6A0791F89C7/0/Britain_Hungary_and_the_Paris_peace_conference_of_1919.pdf ) (16.05.2018) 
Bodolai, Zoltán, The Unmaking of Peace, The Fragmentation and Subsequent Destruction of Central Europe After War One By The Peace Treaty Of Trianon, Australia, 1980.

Cronin, Andrew, "Historical Notes on the Hungarian Peace Delegation of 1920", The News of Hungarian Philately, Volume: 32/Number: 2, Apr-Jun 2001, s. 2-4.

Gazsó, Dániel, "Volt egyszer egy Trianon”, Valóság, (58. évf.) 8. sz., 2015, s. 7088.

Gulyas, László, "A short history of the Treaty of Trianon" (http://www.corvinuslibrary.com/hungary/08gulyas.pdf) (14.06.2018)

Güngörmüş, Naciye, Macaristan'da Değişim ve Demokrasiye Geçiş (1989-2009), Köksav Yayınları, Birinci baskı, Ankara, 2010.

Hajdu, Tibor, “Trianon alternatívája”, Magyar Tudomány, (175. évf.), 11. sz., 2014, s. 1295-1303.

Harmat, Péter Árpád, "A trianoni békeszerződés" (http://tortenelemcikkek.hu/node/244) (23.05.5018)

Ignác, Romsics, “Trianon okai”, s. 1-10.

(http://www.grotius.hu/doc/pub/UUYRSV/2010_122_romsics_ignac_trianon_ok ai.pdf) (12.05.2018).

Juhász, György, “Trianon és a magyar autonómiak - 1918-tól napjainking”, Hitel, (29. évf.), 8. sz., 2016, s. 28-37.

Kohalmi, Csaba L., "Historical Notes on the Hungarian Peace Delegation of 1920", The News of Hungarian Philately, Volume: 32/Number: 2, Apr-Jun 2001, s. 4-6.

Kristó, Gyula - János Barta - Jenő Gergely, Magyarország Története Előidőktől 2000-ig, Pannonica Kiadó, (basım yeri belirtilmemiş) 2002.

Mcneill, William H., Dünya Tarihi, Çev: Alâddin Şenel, İmge Kitapevi, 4. Baskı, Ankara, 1998.

Öz, Ayşe, “Trianon Antlaşması ve Macar Şiirine Yansımaları”, DTCF Dergisi, 57.1, 2017, s. 89-101.

Pomogáts, Béla, "Trianon a történelemben és a magyar irodalomban", Irodalomismeret, 3. sz., 2015, s. 62-68.

Putz, Orsolya, “A figyelemmel kapcsolatos konstruálási müveletek szerepe Trianon konceptualizálásában”, Magyar nyelvör, (138. évf.) 3. sz., 2014, s. 273-296.

"Területcsökkentéstől A Megcsonkítáig Trianon-Metaforák", Élet és Tudomány, LXIX. évfolyam, 23. szám, 2014, s. 723-725.

Renouvin, Pierre, 1. Dünya Savaşı 1914-1918, Çev: Adnan Cemgil, Altın Kitaplar Yayınevi, Üçüncü baskı, (basım yeri belirtilmemiş) 1982.

Roberts, J. M., Avrupa Tarihi, çev: Fethi Aytuna, İnkılap, İstanbul, 2010.

Simon, Andrew L., Admiral Nicholas Horthy: Memoirs, Simon Publications, 2000.

Szakály, Sándor, “Trianon”, Magyar Napló, (21. évf.) 6. sz., 2009, s. 11-14. 
GÖKHAN DİLBAŞ

Szakály, István, “A Trianon-szindróma”, Hitel, (23. évf.), 6. sz., 2010, s. 3-27.

Şen, Muzaffer, Yurt Tutuştan Trianon'a Macaristan, Çizgi Kitabevi, Konya, 2016.

Várdy, Stephen Béla, "The Trianon Syndrome in Today's Hungary", Hungarian Studies Review, Vol. 24, No: 1-2, 1997, s. 73-79.

Vizi, Támás László, "Trianon teóriájánál... rosszabb Trianon praxisa. A békediktátum tizedik évfordulójára - 1930”, Közép-Európai közlemények, (6. évf.) 3. (22) sz., 2013, s. 120-131.

Zeidler, Miklós, Trianon, Treaty of, 1914-1918, International Enciklopedia of the First World War.

https://encyclopedia.1914-1918-online.net/article/trianon_treaty_of

http://www.hunmagyar.org/tor/hungaria.htm (27.05.2018)

http://www.mek.oszk.hu/00700/00708/html/kolto0000/kotet0001/ciklus00486/cim0 0490.htm (28.05.2018)

http://www.tarihin.com/1dunya-savasi/482-ittifak-ve-itilaf-devletleri.html (07.05.2018)

http://www.ataturkinkilaplari.com/avea/57/birinci-dunya-savasi-sonunda-imzalananantlasmalar.html (07.05.2018)

http://www.tariharastirmalari.com/birincidunyasavasi.html (01.06.2018)

http://www.bibl.u-szeged.hu/ha/gazd/stat/ezerev39.html (04.06.2018)

http://www.tarihiolaylar.com/tarihi-olaylar/wilson-ilkeleri-231 (07.06.2018) 